\title{
Saccharibacter floricola gen. nov., sp. nov., a novel osmophilic acetic acid bacterium isolated from pollen
}

\author{
Correspondence \\ Ryosuke Fudou \\ ryosuke_fudou@ajinomoto.com
}

\author{
Yasuko Jojima, ${ }^{1}$ Yasuhiro Mihara, ${ }^{2}$ Sonoko Suzuki, ${ }^{2}$ Kenzo Yokozeki, ${ }^{2}$ \\ Shigeru Yamanaka ${ }^{3}$ and Ryosuke Fudou ${ }^{1}$
1,2Institute of Life Science, Ajinomoto Co. Inc. ${ }^{1}$ and AminoScience Laboratories, Ajinomoto ${ }^{2}$, 1-1 Suzuki-cho, Kawasaki 210-8681, Japan \\ ${ }^{3}$ Faculty of Textile Science and Technology, Shinshu University, Ueda 386-8567, Japan
}

\begin{abstract}
Three Gram-negative, aerobic, rod-shaped bacterial strains were isolated, from the pollen of Japanese flowers, as producers of xylitol; these strains were subjected to a polyphasic taxonomic study. Phylogenetic analyses of the 16S rRNA gene sequences demonstrated that these three isolates formed a new cluster within a group of acetic acid bacteria in the $\alpha$-Proteobacteria. The characteristics of the three isolates were as follows: (i) their predominant quinone was Q-10; (ii) their cellular fatty acid profile contained major amounts of 2-hydroxy acids and an unsaturated straight-chain acid $\left(\mathrm{C}_{18: 1} \omega 7 \mathrm{c}\right)$; and (iii) their DNA $\mathrm{G}+\mathrm{C}$ contents were in the range $51.9-52.3 \mathrm{~mol} \%$, which is around the lower limit of the reported range for the genera of acetic acid bacteria. The negligible or very weak productivity of acetic acid from ethanol and the osmophilic growth properties distinguished these strains from other acetic acid bacteria. The unique phylogenetic and phenotypic characteristics suggest that the three isolates should be classified within a novel genus and species with the proposed name Saccharibacter floricola gen. nov., sp. nov. The type strain is strain S-877 $\left(=\mathrm{AJ} 13480^{\top}=\mathrm{JCM} 12116^{\top}=\mathrm{DSM} 15669^{\top}\right)$.
\end{abstract}

Acetic acid bacteria are generally characterized by their remarkable ability to oxidize alcohols and sugars, and especially by their ability to oxidize ethanol to acetic acid, and they have been widely used for the commercial production of vinegar, gluconate and sorbose. Acetic acid bacteria are currently assigned to six genera in the family Acetobacteraceae, namely Acetobacter, Gluconobacter, Acidomonas, Gluconacetobacter, Asaia and Kozakia, which can be differentiated by means of phenotypic and chemotaxonomic properties (Yamada et al., 2000; Lisdiyanti et al., 2002). On the basis of $16 \mathrm{~S}$ rRNA gene sequence analysis, these bacteria are affiliated to a group of acidophilic bacteria in the $\alpha$-subclass of the Proteobacteria (Sievers et al., 1994). The acetic acid bacteria are known to be well adapted to sugary and alcoholized fluid, their main habitats being vinegar, fruit juice, sap water, alcoholic beverages and flowers.

During the course of a screening programme for microbial producers of xylitol, which is a promising low-calorie

Published online ahead of print on 9 July 2004 as DOI 10.1099/ ijs.0.02911-0.

The GenBank/EMBL/DDBJ accession number for the 16S rRNA gene sequence of strain $\mathrm{S}-877^{\top}$ is $\mathrm{AB} 110421$. sweetener with anti-dental caries properties, we isolated several potent producing strains from flower samples (our unpublished results). Although these strains were found to be in the family Acetobacteraceae (Lisdiyanti et al., 2002), they had rather unusual characteristics for this group of bacteria, such as negligible or weak capacities to produce acetic acid from ethanol and an osmophilic growth profile. In this paper, we report a detailed description of the taxonomic characteristics of these isolates and propose a novel genus and species, Saccharibacter floricola gen. nov., sp. nov., based on physiological and phylogenetic studies.

Three bacterial strains (S-877 ${ }^{\mathrm{T}}, \mathrm{S}-1009$ and S-1019) were isolated from an enrichment culture with a high glucose concentration. The medium used (YUG medium) comprised $1 \cdot 0 \%(\mathrm{w} / \mathrm{v})$ yeast extract (Difco), $0 \cdot 1 \%(\mathrm{w} / \mathrm{v})$ urea and $20 \%(\mathrm{w} / \mathrm{v})$ glucose. After incubation with shaking at $28{ }^{\circ} \mathrm{C}$ for 7 days, the enrichment cultures with flower samples were appropriately diluted and then plated on YUG agar medium [containing $1.5 \%$ (w/v) agar]. For phenotypic characterization and collection of biomass, the strains were cultivated aerobically at $28^{\circ} \mathrm{C}$ using YPG medium $[1 \%(\mathrm{w} / \mathrm{v})$ yeast extract (Difco), $1 \%(\mathrm{w} / \mathrm{v})$ peptone (Difco) and $7 \%(\mathrm{w} / \mathrm{v})$ glucose, adjusted to $\mathrm{pH} 6 \cdot 0$ with $\mathrm{HCl}$ ] unless otherwise specified. Solid media were prepared by adding $1.5 \%(\mathrm{w} / \mathrm{v})$ agar (Difco). 
Cells of all isolates were Gram-negative, strictly aerobic, non-motile rods measuring $0 \cdot 8-1 \cdot 0 \times 2 \cdot 5-4 \cdot 0 \mu \mathrm{m}$. Colonies of the three isolates on YPG agar were circular, entire and pale in colour. Endospores were not produced. The bacterial colonies produced neither soluble pigments, mucous substances nor cellulosic pellicles.

The $16 \mathrm{~S}$ rRNA gene was amplified by a PCR using crude cell lysates, as described by Iizuka et al. (1998). Amplified products were sequenced with a SequiTherm Long-Read cycle sequencing kit (Epicentre Technologies); this was followed by detection with a Pharmacia DNA sequencer according to the manufacturer's instructions. Almost complete 16S rRNA gene sequences of the three isolates were determined and the sequences were aligned with sequences of reference strains in the Acetobacteraceae obtained from the GenBank/EMBL/DDBJ databases. Gaps at the $5^{\prime}$ and $3^{\prime}$ ends of the alignment were omitted and the sequence at positions 46-1506, based on the Escherichia coli numbering system (Weisburg et al., 1991), was used for the final analysis. Nucleotide substitution rates ( $K_{\text {nuc }}$ values) were calculated using Kimura's method (Kimura, 1980). The phylogenetic tree was constructed by the neighbour-joining method (Saitou \& Nei, 1987) with the CLUSTAL W program (Thompson et al., 1994). The robustness of the topology of the neighbour-joining tree was estimated by means of a bootstrapped analysis with 1000 replicates (Felsenstein, 1985). The three isolates shared the same sequences, and a representative isolate $\left(\mathrm{S}-877^{\mathrm{T}}\right)$ constituted a distinct cluster separate from any existing genera in the family Acetobacteraceae (Fig. 1). The tree topology was also supported by maximum-parsimony analysis (data not shown). The sequence similarity levels between isolate $\mathrm{S}-877^{\mathrm{T}}$ and its closest relatives, Gluconobacter cerinus and Gluconobacter oxidans, were $94 \cdot 0$ and $93.9 \%$, respectively. These relatively low similarities warrant the allocation of the novel isolates to a novel genus of acetic acid bacteria.

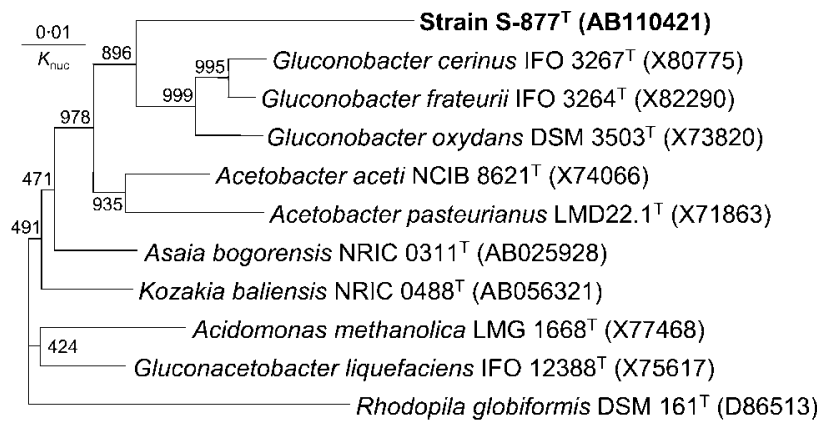

Fig. 1. Neighbour-joining phylogenetic tree showing the relationships of the novel isolates (represented by strain $\mathrm{S}-877^{\top}$ ) and related acetic acid bacteria, based on $16 \mathrm{~S}$ rRNA gene sequences. Bootstrap values, shown at the nodes, were calculated from 1000 samplings. Bar, $1 \%$ estimated sequence divergence.
Isoprenoid quinones were extracted with acetone and analysed by TLC and HPLC according to the method of Hiraishi et al. (1984). The respiratory quinone type of the three isolates was Q-10. Chromosomal DNA was extracted from bacterial cells according to the method of Saito \& Miura (1963) and further purified using a Qiagen Genomic-tip kit. The DNA G $+\mathrm{C}$ content was determined by HPLC using the method of Tamaoka \& Komagata (1984). The G $+\mathrm{C}$ contents of isolates S-877 ${ }^{\mathrm{T}}, \mathrm{S}-1009$ and S-1019 were $52 \cdot 3,52 \cdot 3$ and $51.9 \mathrm{~mol} \%$, respectively. These values are around the lower limit of those of the genera in the family Acetobacteraceae (De Ley et al., 1984; Lisdiyanti et al., 2002). The cellular fatty acid compositions of the isolates were determined using the Microbial Identification System MIDI (Hewlett Packard).

The major fatty acids of the new isolates were a 2-hydroxy acid $\left(\mathrm{C}_{16: 0} 2-\mathrm{OH}\right)$ and a straight-chain unsaturated acid $\left(\mathrm{C}_{18: 1} \omega 7 \mathrm{c}\right)$, which accounted for $31 \cdot 1-41 \cdot 0$ and $22 \cdot 0$ $29 \cdot 8 \%$ of total fatty acids, respectively. The other fatty acids were $\mathrm{C}_{14: 0}(1 \cdot 4-2 \cdot 1 \%), \mathrm{C}_{16: 0} \quad(10 \cdot 0-11 \cdot 1 \%)$, $\mathrm{C}_{19: 0} \omega 8 \mathrm{c}$ cyclo $(2 \cdot 7-3 \cdot 4 \%), \mathrm{C}_{14: 0} \quad 2-\mathrm{OH}(2 \cdot 2-2 \cdot 5 \%)$, $\mathrm{C}_{18: 1} 2-\mathrm{OH}(0 \cdot 8-1 \cdot 0 \%), \mathrm{C}_{14: 0} 3-\mathrm{OH}(4 \cdot 4-7 \cdot 6 \%)$ and $\mathrm{C}_{16: 0} 3-\mathrm{OH}(6 \cdot 4-6 \cdot 9 \%)$. Although these fatty acid profiles were roughly in agreement with reported data for the other genera of acetic acid bacteria (Yamada et al., 1981; Franke et al., 1999), the novel isolates contained unusually high levels of 2-hydroxy fatty acids.

DNA-DNA relatedness was measured according to the dotblot hybridization method (Hiraishi et al., 1991), using a Biodyne A membrane (Gibco-BRL). Labelling of DNA and detection of hybridized DNA were performed using the AlkPhos Direct system for chemifluorescence (Amersham Pharmacia Biotech) according to the manufacturer's directions. Quantification of dots was performed using a fluoroimage analyser (FLA3000; Fuji Film). DNA isolated from $\mathrm{S}-877^{\mathrm{T}}$ hybridized strongly with that from the other two isolates, the similarity values being 71.8 and $99.6 \%$ for strains S-1009 and S-1019, respectively. These results indicate that these three isolates belong to a single species. On the other hand, DNA from Gluconobacter oxydans and Acetobacter aceti, which are representatives of the acetic acid bacteria, showed less than $5 \%$ relatedness with $S 877^{\mathrm{T}}$.

Phenotypic characteristics were examined principally according to Asai et al. (1964) and Yamada et al. (1976, 2000). The three isolates showed rather acidophilic growth, the $\mathrm{pH}$ range for growth of all three strains being $4 \cdot 0-7 \cdot 5$ with an optimum between $\mathrm{pH} 5 \cdot 0$ and $7 \cdot 0$. The temperature range for growth was $20-33^{\circ} \mathrm{C}$ with an optimum around $25-30^{\circ} \mathrm{C}$. The catalase test was positive and the oxidase and indole tests were negative for all three isolates. The isolates showed growth on mannitol agar and glutamate agar supplemented with $7 \%(\mathrm{w} / \mathrm{v})$ glutamate, but they did not grow on normal glutamate agar supplemented with $1 \%(\mathrm{w} / \mathrm{v})$ glutamate. Other phenotypic characteristics are summarized in Table 1. 
Table 1. Characteristics that differentiate Saccharibacter gen. nov. from other genera of acetic acid bacteria

+, Positive; -, negative; W, weakly positive; ND, not determined. Data for reference taxa were taken from Urakami et al. (1989) and Lisdiyanti et al. (2002).

\begin{tabular}{|c|c|c|c|c|c|c|c|}
\hline Characteristic & $\begin{array}{c}\text { Sacchari- } \\
\text { bacter }\end{array}$ & Kozakia & Asaia & $\begin{array}{l}\text { Gluconaceto- } \\
\text { bacter }\end{array}$ & $\begin{array}{l}\text { Glucono- } \\
\text { bacter }\end{array}$ & $\begin{array}{l}\text { Acido- } \\
\text { monas }\end{array}$ & Acetobacter \\
\hline Flagellation & $\begin{array}{l}\text { Non- } \\
\text { motile }\end{array}$ & $\begin{array}{l}\text { Non- } \\
\text { motile }\end{array}$ & $\begin{array}{l}\text { Peritrichous or } \\
\text { non-motile }\end{array}$ & $\begin{array}{l}\text { Peritrichous or } \\
\text { non-motile }\end{array}$ & $\begin{array}{c}\text { Polar or } \\
\text { non-motile }\end{array}$ & $\begin{array}{l}\text { Non- } \\
\text { motile }\end{array}$ & $\begin{array}{l}\text { Peritrichous } \\
\text { or non-motile }\end{array}$ \\
\hline Pigmentation & - & - & $+1-$ & - & + & - & - \\
\hline $\begin{array}{l}\text { Production of water-soluble brown } \\
\text { pigment(s) }\end{array}$ & - & - & - & $+1-$ & $-1+$ & - & - \\
\hline $\begin{array}{l}\text { Production of mucous substance(s) } \\
\text { from sucrose }\end{array}$ & - & + & - & - & - & - & $-1+$ \\
\hline \multicolumn{8}{|l|}{ Oxidation of: } \\
\hline Acetate & - & $\mathrm{W}$ & $\mathrm{W}$ & + & - & + & + \\
\hline Lactate & $\mathrm{W}$ & $\mathrm{W}$ & $\mathrm{W}$ & + & - & - & + \\
\hline $\begin{array}{l}\text { Growth in the presence of } 30 \%(w / v) \\
\text { D-glucose }\end{array}$ & + & - & + & $+1-$ & - & $\mathrm{ND}$ & - \\
\hline \multicolumn{8}{|l|}{ Growth on YPM agar: $\dagger$} \\
\hline Without D-mannitol & - & $\mathrm{w}$ & $\mathrm{W}$ & $\mathrm{w}$ & $\mathrm{w}$ & ND & $\mathrm{W}$ \\
\hline With D-mannitol & + & + & + & + & + & $\mathrm{ND}$ & $\mathrm{W}$ \\
\hline Growth on $1 \%(\mathrm{w} / \mathrm{v})$ glutamate agar & $-\ddagger$ & - & + & + & - & ND & + \\
\hline \multicolumn{8}{|l|}{$\begin{array}{l}\text { Assimilation of ammoniacal nitrogen on } \\
\text { Hoyer-Frateur medium with: }\end{array}$} \\
\hline D-Glucose & - & - & + & $+1-$ & - & $\mathrm{ND}$ & - \\
\hline D-Mannitol & - & - & + & $+1-$ & - & $\mathrm{ND}$ & - \\
\hline Ethanol & - & - & - & - & - & $\mathrm{ND}$ & $+1-$ \\
\hline \multicolumn{8}{|l|}{ Production of keto-D-gluconates from } \\
\hline \multicolumn{8}{|l|}{ D-glucose: } \\
\hline 2-Keto-D-gluconate & + & + & + & + & + & $\mathrm{ND}$ & $+1-$ \\
\hline 5-Keto-D-gluconate & + & + & + & $+1-$ & + & $\mathrm{ND}$ & $+1-$ \\
\hline \multicolumn{8}{|l|}{ Acid production from: } \\
\hline L-Arabinose & + & + & + & $+1-$ & + & - & $+1-$ \\
\hline D-Arabinose & - & $+1-$ & + & - & + & $\mathrm{ND}$ & - \\
\hline D-Xylose & + & + & + & $+1-$ & + & - & $+1-$ \\
\hline L-Rhamnose & - & - & $+1-$ & - & - & ND & - \\
\hline D-Glucose & + & + & + & + & + & + & $+1-$ \\
\hline D-Galactose & + & + & + & + & + & - & $+1-$ \\
\hline D-Mannose & + & + & + & $+1-$ & + & - & $+1-$ \\
\hline D-Fructose & $+1-$ & - & + & + & + & - & - \\
\hline L-Sorbose & - & - & + & $+1-$ & + & ND & - \\
\hline Melibiose & + & + & + & - & + & $\mathrm{ND}$ & - \\
\hline Sucrose & + & $+1-$ & + & - & + & - & - \\
\hline Raffinose & - & + & - & - & - & ND & - \\
\hline D-Mannitol & + & - & $+1-$ & $+1-$ & + & - & - \\
\hline
\end{tabular}


Table 1. cont.

\begin{tabular}{|c|c|c|c|c|c|c|c|}
\hline Characteristic & $\begin{array}{l}\text { Sacchari- } \\
\text { bacter }\end{array}$ & Kozakia & Asaia & $\begin{array}{c}\text { Gluconaceto- } \\
\text { bacter }\end{array}$ & $\begin{array}{c}\text { Glucono- } \\
\text { bacter }\end{array}$ & $\begin{array}{l}\text { Acido- } \\
\text { monas }\end{array}$ & Acetobacter \\
\hline D-Sorbitol & - & - & $+1-$ & - & + & - & - \\
\hline Glycerol & - & + & + & + & + & - & - \\
\hline Ethanol & - & + & - & + & + & + & + \\
\hline
\end{tabular}

${ }^{*}$ For AG broth, see Yamada et al. (2000).

$\dagger$ For YPM agar, see Asai et al. (1964).

‡Growth occurred at $7 \%(\mathrm{w} / \mathrm{v})$ glutamate, but not at $1 \%(\mathrm{w} / \mathrm{v})$ glutamate.

The three isolates differed from Acetobacter, Gluconobacter, Acidomonas, Gluconacetobacter and Kozakia in the lack of production of acetate from ethanol and in the absence of growth in $0.35 \%(\mathrm{v} / \mathrm{v})$ acetic acid at $\mathrm{pH} 3.5$. The isolates could be differentiated from Asaia by the absence of oxidation of acetate and by the absence of assimilation of ammoniacal nitrogen on Hoyer-Frateur medium (De Ley \& Frateur, 1974) with glucose or mannitol.

Another unique property of the three isolates is their osmophilic growth characteristics. To investigate the effect of osmophilic pressure on the growth of the isolates, growth rates at various glucose levels were determined by monitoring optical density at $600 \mathrm{~nm}$ using an automatic growth analyser (Bioscreen C; Labsystems), as shown in Fig. 2. The novel isolate, strain $\mathrm{S}-877^{\mathrm{T}}$, showed not only high osmotolerance but also a requirement for very high glucose levels, growing in the range $5-40 \%(w / v)$, with an optimum at $10 \%(\mathrm{w} / \mathrm{v})$ glucose. In contrast, growth of the

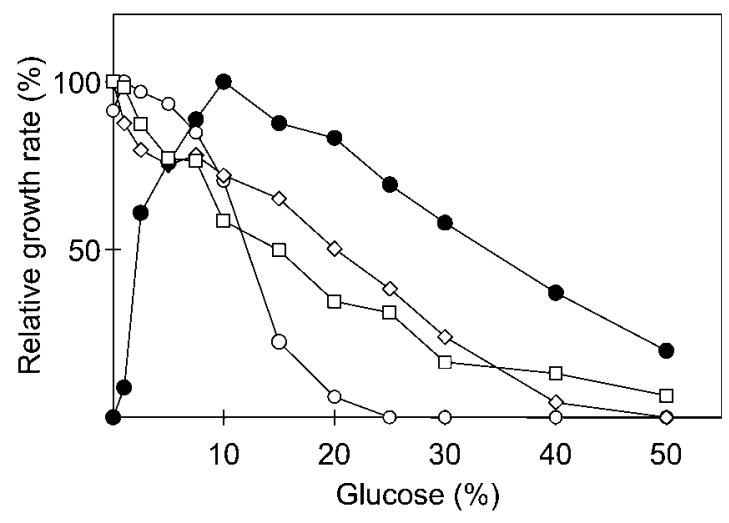

Fig. 2. Effect of glucose concentration on growth of isolate S-877 ${ }^{\top}(\bullet)$, Gluconacetobacter diazotrophicus DSM $5601^{\top}$ $(\diamond)$, Asaia bogorensis JCM $10569^{\top}(\square)$ and Acetobacter aceti NCIB $8621^{\top}(\bigcirc)$. One hundred per-cent growth corresponds to the maximum specific growth rate $\left(\mathrm{h}^{-1}\right)$ under optimum conditions. known 'osmotolerant' species such as Gluconacetobacter diazotrophicus and Asaia bogorensis was inhibited by increased glucose concentrations, although both species were able to grow in the presence of $30 \%(\mathrm{w} / \mathrm{v})$ glucose (Gillis et al., 1989; Yamada et al., 2000). The other isolates (S-1009 and S-1019) showed growth profiles similar to that of strain $\mathrm{S}-877^{\mathrm{T}}$ (data not shown).

In conclusion, the three isolates constitute a distinct phylogenetic lineage among the acetic acid bacteria and have unique phenotypic characteristics, as mentioned above. We propose placement of the isolates in a novel species of a novel genus, namely Saccharibacter floricola gen. nov., sp. nov.

\section{Description of Saccharibacter gen. nov.}

Saccharibacter (Sac.cha.ri.bac'ter. L. neut. n. saccharum or saccharon sugar; N.L. masc. n. bacter from Gr. n. baktron rod; N.L. masc. n. Saccharibacter a rod that grows well in a sugar-rich environment).

Cells are Gram-negative, non-motile, straight rods measuring $0 \cdot 8-1 \cdot 0 \times 2 \cdot 5-4 \cdot 0 \mu \mathrm{m}$. Chemo-organotrophic and strictly aerobic. Catalase-positive. Oxidase-negative. Nonpigmented. Produces neither cellulosic pellicles nor watersoluble mucous substances. The optimum $\mathrm{pH}$ for growth is around $5 \cdot 0-7 \cdot 0$; there is no growth above $\mathrm{pH} 8 \cdot 0$ or below $\mathrm{pH} 4 \cdot 0$. Growth occurs in the glucose range $2-40 \%$ $(\mathrm{w} / \mathrm{v})$, with an optimum around $10 \%(\mathrm{w} / \mathrm{v})$. Grows on mannitol and $7 \%(\mathrm{w} / \mathrm{v})$ glutamate agar but not on $1 \%$ $(w / v)$ glutamate agar. Forms negligible or very little acetic acid from ethanol. Produces gluconic acid, 2-keto-Dgluconic acid and 5-keto-D-gluconic acid from glucose. Prefers high glucose concentration for growth [e.g. $10 \%$ (w/v) glucose]. Does not oxidize acetate to $\mathrm{CO}_{2}$ and water. Oxidation of lactate is weak. Ammonia is not assimilated on Hoyer-Frateur medium with glucose, mannitol or ethanol. Does not utilize methanol. Does not produce dihydroxyacetone from glycerol. Acid is produced from L-arabinose, D-xylose, D-glucose, D-galactose, D-mannose, melibiose, sucrose and mannitol, but not from D-arabinose, 
L-rhamnose, L-sorbose, raffinose, D-sorbitol, dulcitol, glycerol or ethanol. Production of acid from L-sorbose is variable. The DNA G $+\mathrm{C}$ content is about $52-53 \mathrm{~mol} \%$. The major quinone type is $\mathrm{Q}-10$. The major cellular fatty acids are a 2-hydroxy acid $\left(\mathrm{C}_{16: 0} 2-\mathrm{OH} ; 31 \cdot 1-41 \cdot 0 \%\right)$ and a straight-chain unsaturated acid $\left(\mathrm{C}_{18: 1} \omega 7 c ; 22 \cdot 0-29 \cdot 8 \%\right)$. The type species is Saccharibacter floricola.

\section{Description of Saccharibacter floricola sp. nov.}

Saccharibacter floricola (flo.ri.co'la. L. n. flos -oris a flower; L. suff. - cola derived from L. n. incola a dweller; N.L. n. floricola flower-dweller).

Has all the characteristics that define the genus. Strains have been isolated from Japanese flowers.

The type strain is strain $\mathrm{S}-877^{\mathrm{T}}\left(=\mathrm{AJ} 13480^{\mathrm{T}}=\mathrm{JCM}\right.$ $12116^{\mathrm{T}}=\mathrm{DSM} 15669^{\mathrm{T}}$ ), which was isolated from pollen collected in Kanagawa Prefecture, Japan. The DNA G $+\mathrm{C}$ content of strain $\mathrm{S}-877^{\mathrm{T}}$ is $52 \cdot 3 \mathrm{~mol} \%$.

\section{Acknowledgements}

The authors wish to thank Dr Kazuo Komagata, Professor Emeritus of Tokyo University, for reading the manuscript and providing useful comments.

\section{References}

Asai, T., lizuka, H. \& Komagata, K. (1964). The flagellation and taxonomy of genera Gluconobacter and Acetobacter with reference to the existence of intermediate strains. J Gen Appl Microbiol 10, 95-126.

De Ley, J. \& Frateur, J. (1974). Genus Acetobacter Beijerinck 1898, $215^{\mathrm{AL}}$. In Bergey's Manual of Determinative Bacteriology, 8th edn, pp. 276-278. Edited by R. E. Buchanan \& N. E. Gibbons. Baltimore: Williams \& Wilkins.

De Ley, J., Swings, J. \& Gosselé, F. (1984). Genus I. Acetobacter Beijerinck 1898, 215 ${ }^{\mathrm{AL}}$. In Bergey's Manual of Systematic Bacteriology, vol. 1, pp. 268-274. Edited by N. R. Krieg \& J. G. Holt. Baltimore: Williams \& Wilkins.

Felsenstein, J. (1985). Confidence limits on phylogeny: an approach using the bootstrap. Evolution 39, 783-791.

Franke, I. H., Fegan, M., Hayward, C., Leonard, G., Stackebrandt, E. \& Sly, L. I. (1999). Description of Gluconacetobacter sacchari sp. nov., a new species of acetic acid bacterium isolated from the leaf sheath of sugar cane and from the pink sugar-cane mealy bug. Int J Syst Bacteriol 49, 1681-1693.

Gillis, M., Kersters, K., Hoste, B., Janssens, D., Kroppenstedt, R. M., Stephan, M. P., Teixeira, K. R. S., Döbereiner, J. \& De Ley, J. (1989). Acetobacter diazotrophicus sp. nov., a nitrogen-fixing acetic acid bacterium associated with sugarcane. Int J Syst Bacteriol 39, 361-364.

Hiraishi, A., Hoshino, Y. \& Kitamura, H. (1984). Isoprenoid quinone composition in the classification of Rhodospirillaceae. J Gen Appl Microbiol 30, 197-210.

Hiraishi, A., Hoshino, Y. \& Satoh, T. (1991). Rhodoferax fermentans gen. nov., sp. nov., a phototrophic purple nonsulfur bacterium previously referred to as the "Rhodocyclus gelatinosus-like" group. Arch Microbiol 155, 330-336.

lizuka, T., Yamanaka, S., Nishiyama, T. \& Hiraishi, A. (1998). Isolation and phylogenetic analysis of aerobic copiotrophic ultramicrobacteria from urban soil. J Gen Appl Microbiol 44, 75-84.

Kimura, M. (1980). A simple method for estimating evolutionary rates of base substitutions through comparative studies of nucleotide sequences. J Mol Evol 16, 111-120.

Lisdiyanti, P., Kawasaki, H., Widyastuti, Y., Saono, S., Seki, T., Yamada, Y., Uchimura, T. \& Komagata, K. (2002). Kozakia baliensis gen. nov., sp. nov., a novel acetic acid bacterium in the $\alpha$-Proteobacteria. Int J Syst Evol Microbiol 52, 813-818.

Saito, H. \& Miura, K. (1963). Preparation of transforming deoxyribonucleic acid by phenol treatment. Biochim Biophys Acta 72, 619-629.

Saitou, N. \& Nei, M. (1987). The neighbor-joining method: a new method for reconstructing phylogenetic trees. Mol Biol Evol 4, 406-425.

Sievers, M., Ludwig, W. \& Teuber, M. (1994). Phylogenetic positioning of Acetobacter, Gluconobacter, Rhodopila and Acidophilum species as a branch of acidophilic bacteria in the $\alpha$-subclass of Proteobacteria based on 16S rDNA sequences. Syst Appl Microbiol 17, 189-196.

Tamaoka, J. \& Komagata, K. (1984). Determination of DNA base composition by reversed-phase high-performance liquid chromatography. FEMS Microbiol Lett 25, 125-128.

Thompson, J. D., Higgins, D. G. \& Gibson, T. J. (1994). CLUSTAL W: improving the sensitivity of progressive multiple sequence alignment through sequence weighting, position-specific gap penalties and weight matrix choice. Nucleic Acids Res 22, 4673-4680.

Urakami, T., Tamaoka, J., Suzuki, K. \& Komagata, K. (1989). Acidomonas gen. nov., incorporating Acetobacter methanolicus as Acidomonas methanolica comb. nov. Int J Syst Bacteriol 39, 50-55.

Weisburg, W. G., Barns, S. M., Pelletier, D. A. \& Lane, D. J. (1991). $16 \mathrm{~S}$ ribosomal DNA amplification for phylogenetic study. J Bacteriol 173, 697-703.

Yamada, Y., Okada, Y. \& Kondo, K. (1976). Isolation and characterization of "polarly flagellated intermediate strains" in acetic acid bacteria. J Gen Appl Microbiol 22, 237-245.

Yamada, Y., Nunoda, M., Ishikawa, T. \& Tahara, Y. (1981). The cellular fatty acid composition in acetic acid bacteria. J Gen Appl Microbiol 27, 405-417.

Yamada, Y., Katsura, K., Kawasaki, H., Widyastuti, Y., Saono, S., Seki, T., Uchimura, T. \& Komagata, K. (2000). Asaia bogorensis gen. nov., sp. nov., an unusual acetic acid bacterium in the $\alpha$-Proteobacteria. Int J Syst Evol Microbiol 50, 823-829. 